\title{
INSTITUTIONAL FANTASYLANDS: FROM SCIENTIFIC MANAGEMENT TO FREE MARKET ENVIRONMENTALISM
}

\author{
Peter S. Menell*
}

A decade ago, John Baden and Richard Stroup introduced their insightful and provocative edited volume, Bureaucracy $v$. Environment, with the following research agenda:

[W] are increasingly convinced that both the environmental and the economic costs of bureaucratic management of natural resources are excessively and unnecessarily high. . . . While explanations of failure in the private sector are generally understood and have been incorporated into syllabi for at least a generation, the public sector has only recently received comparable attention. ${ }^{1}$

Building upon the developing public choice literature, which uses economic analysis to understand and explain the decisions made by government actors, this volume focused attention on the failures of governmental management of natural resources. It exposed the inefficiency of resource extraction on public lands, overgrazing of federal lands, overdevelopment of water resources, and wasteful harvesting practices in national forests.

On the tenth anniversary of the publication of Bureaucracy $v$ s. Environment, Terry Anderson and Donald Leal have released Free Market Environmentalism, ${ }^{2}$ a concise synthesis and ambitious projection of this rapidly evolving program of resource policy analysis. ${ }^{3}$ The New Resource Economics is no longer confined to natural resource problems. Anderson and Leal advocate complete reliance on free market principles to address all environmental problems. ${ }^{4}$ Their book suggests ways of applying

- Acting Professor of Law, University of California at Berkeley School of Law (Boalt Hall). S.B., Massachusetts Institute of Technology, 1980; J.D., Harvard Law School, 1986; Ph.D. (economics), Stanford University, 1986. I am grateful to Tim Burns, Dan Farber, Gillian Hadfield, Eric Rakowski, and Joe Sax for useful comments on an earlier draft.

1. John Baden \& Richard L. Stroup, Introduction to BurEaucracy vs. ENvironment: The Environmental. Costs of Bureaucratic Governance 1 (John Baden \& Richard L. Stroup eds., 1981) [hereinafter BuREaUCRACY vs. ENVIRONMENT].

2. Terry L. Anderson \& Donald R. Leal, Free Market Environmentalism (1991).

3. A comparison of the bibliographies of these two works illustrates the field's growth: the bibliography of FreE MARKET ENVIRONMENTALISM contains 244 entries, more than five times as many as BUREAUCRACY vs. ENVIRONMENT.

4. ANDERSon \& Leal, supra note 2 , at 3 . 
these ideas to air and water pollution, regulation of hazardous materials, and global climate change, among others. It is no exaggeration to say that Anderson and Leal would privatize all resources and abolish all regulatory agencies other than common law courts and those ancillary government offices necessary for defining and enforcing property rights.

Just as traditional economic analysis of environmental problems, such as promoting government intervention to counteract the market's inability to regulate externalities, often ignores the imperfections of public institutions, the free market environmentalist perspective reflects a comparably naive view of institutions by focusing narrowly and simplistically upon the delineation and enforcement of property rights. This article exposes the utopian parallels between scientific management and free market environmentalism by exploring the limitations of Anderson and Leal's analytical framework.

\section{Scientific Management: Economists and Resource MANAGERS IN FANTASYLAND}

The traditional economic approach to environmental protection champions government intervention as an effective remedy for a host of market failures, most notably externalities. ${ }^{5}$ The familiar explanation, presented in most economics and public policy texts, goes as follows: Because private entities do not bear the full environmental costs of their activities, they will tend to overgraze the commons, overuse and befoul the water, and pollute the air. ${ }^{6}$ Government intervention can assure a "first-best" allocation of resources by "scientifically" managing the commons and "internalizing" externalities through appropriate taxes or standards. Bureaucrats need merely analyze resource management issues using the tools of modern economic analysis, resource management, and ecology to determine the efficient public policy.

The problem with this simple prescription is that the cure is so rarely obtained in reality. Government management of resources frequently results in overgrazing of the commons. Federal and state water policies have aggravated the depletion of

5. See, e.g., Charles W. Howe, Natural Resource Economics 103, 336-37 (1979).

6. See, e.g., Paul A. Samuelson \& William D. Nordhaus, Economics 715-18 (12th ed. 1985). 
water resources in the West. ${ }^{7}$ Fish stocks in U.S. coastal waters have dwindled far below maximum sustainable yield despite Federal control of fishing. ${ }^{8}$ In fact, public management of resources has on occasion led to worse over-exploitation than would have resulted from unregulated private ownership. It is unlikely, for example, that private forest owners would harvest timber worth less than the cost of acquisition, yet the revenue from the sale of timber on public lands frequently falls below the government's costs of making this timber available. ${ }^{9}$ Nor has government regulation achieved air and water quality goals. While the Clean Air Act of $1970^{10}$ promised clean air by 1975 , its air quality goals have yet to be attained in most urban areas. ${ }^{11}$ Water quality goals are similarly behind schedule. ${ }^{12}$ Furthermore, the regulatory programs have conspicuously failed to minimize the costs of pollution abatement. ${ }^{13}$

As highlighted in the introductory chapters of Free Market Environmentalism, public choice theory provides powerful insights into why "scientific management" of natural resources and environmental pollution has often failed to allocate resources efficiently in practice. ${ }^{14}$ Public choice theorists model legislation and regulation as outcomes of market-like processes. ${ }^{15}$ Legislators, motivated by the desire to stay elected, form the supply side of the market, while interest groups form the demand side. Transactions are most likely to occur when the benefits of legislation are concentrated and the costs are distributed broadly. In these circumstances, the few

7. See Robert Stavins et al., Project 88-Round II, Incentives for Action: Designing Market-Based Environmental Strategies 70 (1990) [hereinafter Project 88].

8. See Peter Passell, U.S. Starts to Allot Fishing Rights in Coastal Waters to Boat Owners, N.Y. Times, April 22, 1991, at Al.

9. In 1989, 102 out of 120 National Forests produced net losses, resulting in total losses of $\$ 365$ million-in 48 forests, revenues were less than $10 \%$ of costs. See Project 88, supra note 7 , at 78-79.

10. 42 U.S.C. $\$ \S 7401-7642$ (1988).

11. See Paul R. Portney, Air Pollution Policy, in Public Policies for Environmental Protection 27-96 (Paul R. Portney ed. 1990) [hereinafter Public Policies].

12. See A. Myrick Freeman, Water Pollution Policy, in Public Policies, supra note 11, at 97-149.

13. See Bruce A. Ackerman \& Richard B. Stewart, Reforming Environmental Law, 37 Stan. L. Rev. 1333, 1334-40 (1985); Robert W. Crandall, Controlling Industrial Pollution (1983).

14. See also Bureaucracy vs. Environment, supra note 1, at 4-5.

15. For a lucid and concise summary of public choice theory, see William N. Eskridge, Jr., Politics Without Romance: Implications of Public Choice Theory for Statutory Interpretation, 74 VA. L. REv. 275, 285-90 (1988). 
who benefit greatly have strong incentives to organize in order to influence the political process, while the many who lose little individually, but much collectively, must overcome substantial free-rider problems in organizing to defeat such "rent-seeking" legislation. The forestry and water subsidy programs seem to fit nicely within this category. Timber interests and farmers reap concentrated gains, while taxpayers suffer individually small but collectively large losses.

Conversely, legislation is less likely where the benefits of regulation are distributed and the costs are concentrated; those bearing the costs have a strong incentive to organize, while the many diffuse recipients face substantial free-rider problems. The political outcomes in these situations tend to be no legislation or delegation to a regulatory agency prone to capture by the interest groups bearing the concentrated costs. Early pollution control legislation such as the Clean Air Act Amendments of $1970,{ }^{16}$ featuring strong symbolic language but vague regulatory requirements, seems to reflect this interest group pattern. ${ }^{17}$

\section{Free Market ENVIRoNMENTALism: LibertarianS in Fantasyland}

- While sensitive to the questionable assumptions underlying much traditional economic analysis of natural resource and environmental problems, Anderson and Leal fail to scrutinize the extreme assumptions implicit in their own analysis. To their credit, Anderson and Leal recognize that "first-best" allocations of resources are not achievable in a world with transaction costs. ${ }^{18}$ Yet, they unabashedly claim that clearly defined and enforced property rights will achieve the best possible allocation of resources, regardless of the environmental context. ${ }^{19}$ This conclusion, however, rests upon largely unexamined assumptions about the nature of human behavior, the smooth functioning of markets, the efficacy of legal institutions, and the complete incompetence of public institutions. ${ }^{20} \mathrm{~A}$ brief review

16. Clean Air Act Amendments of 1970, Pub. L. No. 91-604, 84 Stat. 1676 (1970) (codified as amended in scattered sections of 42 U.S.C.).

17. See John Dwyer, The Pathology of Symbolic Legislation, 17 Ecol. L.Q. 233 (1990).

18. ANDERSon \& Leal, supra note 2, at 17-23.

19. See id. at 21-23.

20. It should also be noted that Anderson and Leal pay no attention to distributional 
of these assumptions reveals the fantasy of Anderson and Leal's world.

\section{A. The Model of Human Nature}

As a basis for their analysis, Anderson and Leal employ the standard economic model of human nature: Human beings are self-interested, rational actors who seek to maximize their utility. ${ }^{21}$ Although this model is a useful predictor of human behavior, it compromises accuracy in order to increase tractability. Convenience alone, however, does not justify uncritical invocation of such simplifications, especially where there is good reason to believe that these assumptions introduce significant biases into the analysis. Since the limitations of the standard economic model of human nature are explored generally elsewhere, ${ }^{22}$ I focus here upon four shortcomings of special relevance to natural resource and environmental issues: the failure to consider the endogeneity of preferences, the formation and expression of preferences through democratic processes, the endowment effects associated with allocations of ownership, and the role of culture in guiding human behavior.

\section{Failure to Consider the Endogeneity of Preferences}

Within the standard economic model of human nature, a person's preferences are determined exogenously (that is, are innate to the individual) and are assumed to be fixed. ${ }^{23}$ To Homo Economicus, the environment represents simply an array of resources to be consumed or otherwise enjoyed. This assumption is critical to Anderson and Leal's contention that only privately mutually-beneficial trades can improve social welfare. ${ }^{24}$

For many private consumption decisions, the assumption of exogenous and fixed preferences seems reasonable. It is unlikely that the quality of running shoes, the comfort of a chair, or the taste of a good wine will influence one's character in

issues raised by extensive reliance upon private property institutions to address natural resource and environmental issues.

21. ANDERSON \& LEAL, supra note 2, at 4.

22. See Robert C. Ellickson, Bringing Culture and Human Frailty to Rational Actors: $A$ Critique of Classical Law and Economics, 65 CHI.-KENT L. Rev. 23 (1989); AMtTAI ETZIONI, The Moral Dimension: Toward a New Economics (1988); Jack Hirshleifer, The Expanding Domain of Economics, 75 AM. Econ. Rev. 53 (Supp. Issue No. 6, Dec. 1985).

23. See George J. Stigler \& Gary S. Becker, De Gustibus Non Est Disputandum, 67 Aм. ECON. REv. 76 (Mar. 1977).

24. See ANDERSon \& Leal, supra note 2, at 17-23. 
deep and integral ways. Major resource decisions, however, particularly those affecting the range of environmental experiences available, can have a more profound effect on human nature. ${ }^{25} \mathrm{~A}$ completely private economy might generate greater homogeneity of environmental experiences, such as more theme parks and fewer pristine valleys, than a mixed economy, because of the desire to maximize appropriable return on investment in the development of resources. In view of the uniqueness of some environmental resources and the effective irreversibility of their development, such a diminution in the range of opportunities for formative experiences would no doubt alter individuals' developmental processes. ${ }^{26}$ The effect of wilderness experience on human development is a principal theme in the writings of generations of American naturalists. ${ }^{27}$ The growing concern for the environment has been significantly influenced by the opportunities for a broad range of nature experiences as well as the rich tradition of naturalist writers inspired by such experiences. ${ }^{28}$ Thus, human appreciation of the environment is more aptly viewed as an outgrowth of a diversity of environmental opportunities, rather than an exogenous set of tastes.

It is possible, of course, that a market could capture some of the value inherent in a range of resource opportunities, although this type of value, because of its intangible quality, might be particularly difficult to appropriate through markets. For example, the Sierra Club might purchase Yosemite Valley and preserve it in its natural state. This does not mean, however, that the "private" preferences of Sierra Club members as manifested in the collective decisions of the Sierra Club will necessarily reflect the full potential value of such resources since human appreciation of nature may be inchoate. Because preferences may be undeveloped, futures markets for such resources might be particularly difficult to establish. The thresh-

25. See Cass R. Sunstein, Legal Interference with Private Preferences, 53 U. CH. L. REv. 1129 (1986); Richard B. Stewart, The Reformation of American Administrative Law, 88 HARV. L. REV. 1704-05 (1975).

26. See Richard B. Stewart, Regulation in a Liberal State: The Role of Non-Commodity Values, 92 Yale L.J. 1567-68 (1983). Cf. Joseph L. Sax, Mountains Without Handrails (1980).

27. See generally Roderick Nash, Wilderness and the American Mind (3d ed. 1982).

28. See Henry D. Thoreau, IN Wildness Is the Preservation of the World (Eliot Porter ed., 1962). 
old question is whether public institutions have a role in ensuring a diversity of physical environments. Admittedly, any such decision process invites the abuses of public institutions detailed by public choice theory. Nonetheless, the potential for endogenous preference change raises serious questions about the choice and roles of institutional structures. This set of concerns is clearly relevant to a liberal society's development and enrichment, yet remains outside the reach of the standard economic model of human nature.

\section{Expression of Preferences Through Democratic Processes}

A related critical assumption of Anderson and Leal's framework is its rejection of any legitimate role for public institutions and democratic processes in the formation and expression of preferences. The only preferences in Anderson and Leal's world are those of individuals and private organizations, such as the Nature Conservancy, expressed through markets. ${ }^{29}$ Public institutions are incapable of legitimately expressing the will of the people. This cramped view not only conflicts with the foundation of our democratic society, but also ignores two important considerations for any institutional analysis: the role of collective bodies in the formation of preferences and the choice of institutional devices for reflecting preferences.

The first consideration requires some stretching of the traditional economic framework to incorporate the role of collective bodies, whether public or private, in the formation of collective preferences. Whether the Nature Conservancy, the Sierra Club, the Environmental Protection Agency, or the U.S. Congress, collective bodies operate in our society as important fountains of social values by combining different elements of expertise, representation, and legitimacy. Their views may carry diverse normative significance. ${ }^{30}$ Anderson and Leal seem comfortable in allowing private organizations, such as the Nature Conservancy, to perform this role, ${ }^{31}$ but dismiss any role for public institutions based on a cursory public choice analysis. ${ }^{32}$ This posture, however, precludes thorough comparative analysis of

29. See ANDERSON \& LeAL, supra note 2, at 3.

30. See Joseph L. Sax, The Legitimacy of Collective Values: The Case of the Public Lands, 56 U. Colo. L. Rev. 537, 544 (1985).

31. See Anderson \& LEAL, supra note 2, at 3. As is discussed below, infra note 51, Anderson and Leal's enthusiasm for private organizations is not without some irony.

32. See id. at 12-17. 
institutions for the diverse set of natural resource and environmental issues.

The second consideration, the choice of institutional devices for reflecting preferences, calls for an analysis of the transaction and other costs associated with different institutional structures. Anderson and Leal prefer to limit the analysis to individuals and private organizations, but a complete analysis would also recognize the potential for public institutions to perform this function. Although the potential for abuse may be greater from public institutions because of the coercive power of government and public choice problems, there are also potential benefits from the unique institutional attributes of public institutions, such as economies of scale and the ability to overcome holdouts. In addition, devices such as constitutional checks and judicial oversight may be able to limit the potential for abuse. This is not to say that public institutions necessarily dominate the market, but rather that the possibility justifies their consideration in conducting comparative institutional analysis.

\section{Endowment Effects Associated with Allocation of Ownership}

A third shortcoming of Anderson and Leal's analytical framework relates to the potential role of public ownership in the valuation and enjoyment of resources. Substantial empirical evidence indicates a significant divergence between consumers' willingness to pay for resources and their willingness to accept compensation for the loss of such resources. ${ }^{33}$ This phenomenon, often referred to as the endowment effect, suggests that the utility people derive from the use of resources depends upon their perception of ownership of such resources. One survey found that hunters were willing to pay an average of $\$ 247$ to preserve a wetland hunting area but would require

33. See Don L. Coursey et al., The Disparity Between Willingness to Accept and Willingness to Pay Measures of Value, 102 Q.J. OF ECON. 679 (1987). This phenomenon might be reconcilable with economic notions of rationality, see W. Michael Hanemann, Willingness to Pay and Willingness to Accept: How Much Can They Differ?, 81 Am. Econ. Rev. 635 (1991), although other frameworks might be more explanatory. See Mark Kelman, Consumption Theory, Production Theory, and Ideology in the Coase Theorem, 52 S. CAL. L. Rev. 669, 678-79, 681 (1979). This disparity has some resonance with the empirical work of cognitive psychologists finding that people place a higher value on the loss of a "vested" right than the loss of a prospect, a psychologically unvested right. See Amos Tversky \& Daniel Kahnemen, Rational Choice and the Framing of Decisions, 59 J. Bus. S251 (1986); see also Ellickson, supra note 22, at 35-40. 
more than four times that amount to give up an entitlement to that same area. ${ }^{34}$ Holding resources in the public domain may create a broader group of perceived "owners," even though the degree of ownership in terms of exclusive rights is diminished. It is an empirical question whether the value attached to public ownership of a national park in which there are 250 million owners with limited rights, such as access and protection against certain uses, exceeds the value of the same land held by one or a few owners with a more complete bundle of property rights. Anderson and Leal ignore these issues by implicitly assuming that the choice is between no ownership and private ownership.

The endowment effect may also suggest that the experience of using one's own resources, for example, hiking in a "public" park, might be more enjoyable even if a user fee is charged than the experience of renting comparable resources (for example, hiking in a similar "private" park charging the same user fee) ${ }^{35}$ This does not necessarily mean that the best public policy is a preference for public rather than private ownership in all circumstances. As Anderson and Leal have highlighted, private parks might be better maintained than public parks. ${ }^{36}$ Furthermore, the empirical significance of this effect is a limiting factor. ${ }^{37}$ Nonetheless, this phenomenon suggests an additional trade-off between public and private institutions that is not captured by Anderson and Leal's analytical framework.

\section{The Role of Culture in Guiding Human Behavior}

A fourth oversimplified assumption of the standard economic model of human nature is the atomistic quality of human decisionmaking. While this assumption is a useful first approximation of human behavior, it obscures the important role of culture and norms in determining behavior in many natural re-

34. Judd Hammaker \& Gardner Mallard Brown, JR., Waterfowl and Wetlands: TOWARD BIoEConomic ANalysis (1974).

35. Of course, holding user fees constant, the value derived from hiking in a private preserve might be considered more valuable to some people than the experience of hiking in a comparable public preserve. This possibility reinforces the point. Systematic "non-rational" elements of human nature should influence the analysis of institutional choice.

36. See ANDERSon \& LeAl, supra note 2, at 51-52.

37. Cf. Hanemann, supra note 33, at 635. But cf. Herbert Hovenkamp, Legal Policy and the Endowment Effect, 20 J. LEGAL STuD. 225, 227-28 (1991) (describing studies finding particularly large endowment effects for wildlife preservation and environmental quality). 
source and environmental settings. Numerous examples from history and current societies suggest that the commons will not automatically be overgrazed. ${ }^{38}$ The decisions of individuals depend upon context, community structure, and shared values, concepts not easily incorporated within an atomistic framework of human behavior.

When market regulation of external effects is costly, for example, because of the high costs of fencing or monitoring use, the fostering of cooperative norms and other social control devices might prove a more effective institutional structure than complete reliance on the market. Yet a framework built entirely on atomistic action will exclude such possibilities. The norms among backpackers of carrying out refuse and not "relieving themselves" near streams are examples where non-market control systems might regulate externalities effectively. Of course, the market is not irrelevant to addressing the problems of overuse. User fees can be an effective means of addressing some overuse and congestion problems in scenic areas. ${ }^{39}$ Nonetheless, comprehensive institutional analysis should consider the potential for non-market systems of allocating resources, a task that requires a more sophisticated model of human behavior than that which Anderson and Leal employ.

This discussion of particular shortcomings of the standard economic model of human nature is by no means intended as a complete rejection of Anderson and Leal's analysis. Rather, the purpose of these observations is to highlight some significant, although admittedly less tangible, factors that are obscured by their framework, yet remain relevant to a full comparative analysis of institutions for natural resource and environmental policy. The principal limitations of their analysis lie in their

38. See, e.g., Henry Hansmann, When Does Worker Ownership Work? ESOPs, Law Firms, Codetermination, and Economic Democracy, 99 YaLE L.J. 1749 (1990); Robert C. Ellickson, $A$ Hypothesis of Wealth-Maximizing Norms: Evidence from the Whaling Industry, $5 \mathrm{~J}$.L. EcoN. \& OrG. 83 (1989); Robert C. Ellickson, Of Coase and Caltle: Dispute Resolution Among Neighbors in Shasta County, 38 Stan. L. Rev. 623 (1986); Ronald J. Gilson \& Robert H. Mnookin, Sharing Among the Human Capitalists: An Economic Inquiny into the Corporate Law Firm and How Partners Split Profits, 37 Stan. L. Rev. 313 (1985); Carol Rose, The Comedy of the Commons: Custom, Commerce, and Inherently Public Property, 53 U. CHI. L. Rev. 711 (1986); Gordon Tullock \& John Baden, Communes and the Logic of the Commons, in ManacING THE Commons (Garrett Hardin \& John Baden eds., 1977).

39. Nor could it be shown that liability rules with probabilistic enforcement would clearly dominate non-market approaches. $C f$. A. Mitchell Polinsky \& Stephen Shavell, $A$ Note on Optimal Fines When Wealth Varies Among Individuals, 81 AM. EcoN. Rev. 618 (1991). 
simplistic characterization of market, legal, and public institutions.

\section{B. Markets and Transaction Costs}

The primary attack on free markets in many environmental contexts is their failure to internalize external costs. As Professor Coase highlighted in his seminal article on social cost, ${ }^{40}$ however, the problem of externalities can be restated as a problem of incomplete markets. When the costs of forming markets are low and the benefits to be gained are significant, markets will develop to internalize external effects.

Building upon this insight, property rights theorists have developed a rich positive theory of the evolution of property rights. Professor Demsetz suggested that "property rights arise when it becomes economic for those affected by externalities to internalize benefits and costs." 41 Elaborating this framework, Professor Pejovich highlighted the fact that market forces will generate new technologies for defining and enforcing property rights. ${ }^{42}$ As Anderson has described in an earlier work, ${ }^{43}$ the evolution of property rights systems in the American West, from the enclosure of land to the definition of water rights, reflected these forces. The invention and diffusion of barbed wire in the latter part of the Nineteenth Century miraculously transformed a vast commons into an effective system of private property. ${ }^{44}$

Resolute confidence in this evolutionary theory forms the linchpin of Anderson and Leal's reliance upon free market forces to resolve all externality problems in the most efficacious manner. This approach to institutional choice, however, confuses positive and normative analysis of institutions. The empirically significant relationship between the social gains from

40. Ronald H. Coase, The Problem of Social Cost, 3 J.L. \& Econ. 1 (1960).

41. Harold Demsetz, Toward a Theory of Property Rights, 57 Am. ECON. Rev. 347, 354 (Papers \& Proc. 1967).

42. Svetozar Pejovich, Towards an Economic Theory of the Creation of Property Rights, 30 Rev. Social Econ. 309, 310, 316 (1972).

43. Terry L. Anderson \& P.J. Hill, The Evolution of Property Rights: A Study of the American West, 18 J.L. \& Econ. 163 (1975). This article is summarized in Chapter 3 of Free Market Environmentalism.

44. See Anderson \& Leal, supra note 2, at 31-32. Changes in values, however, have cast some doubt on the desirability of this innovation. Concern for wildlife preservation may be supplanting (at a minimum, is competing with) the earlier desire to establish a cattle-and-pasture system of land use in the West. See, e.g., James Barron, Audubon Show Irks Cattle Ranchers, N.Y. Times, July 31, 1991, at Cl1. 
propertization and the formation of markets in no way demonstrates that markets will form whenever resources could be allocated more efficiently. Only by assuming the complete undesirability of public institutions or low costs of market formation and operation for all significant natural resource and environmental problems does the normative conclusion follow. The first condition, the utter incompetence of public institutions, is taken up in section $\mathrm{D}$ below. The second condition deserves further comment here.

Anderson and Leal emphasize three mechanisms by which markets will respond to the principal natural resource and environmental problems: (1) the formation of cooperative organizations to channel demand for natural resource and environmental protection; (2) technological innovations that dramatically reduce the costs of market solutions; and (3) the use of common law courts to protect private property. ${ }^{45}$

In circumstances in which people derive benefits from the protection of a natural resource, they are free to form a consortium to purchase such resources or negotiate restrictions upon their use. Anderson and Leal recognize the free-rider problems impeding such cooperatives, but are encouraged by the success of a few such organizations like the Nature Conservancy and the Anglers' Cooperative Association in England. ${ }^{46}$ Clearly the formation of such organizations and the successful negotiation of conservation easements or other agreements is to be applauded. In view of the high transaction costs of forming such consortia, however, the failure of such free market solutions to materialize does not necessarily demonstrate that protection of a resource is undesirable. Other institutional arrangements, even if imperfect, may be preferable to relying exclusively upon the market in these circumstances. Anderson and Leal present a strong case for why such cooperatives are valuable institu-

45. See ANDERSon \& LEAL, supra note 2, at 164-67.

46. See id. at 148, 164. Anderson and Leal's celebration of such organizations is not without some irony. As cooperative institutions, these organizations do not rely exclusively upon market forces to guide their decisions. Moreover, since the principal benefits of contributing to the Nature Conservancy and similar organizations can be derived without paying, it is difficult to square the viability of such organizations with the standard economic model of human nature. Furthermore, large "cooperative" organizations begin to take on the qualities of government, as is evidenced by the elaborate governing mechanisms found in large "private" communities. See Robert C. Ellickson, Cities and Homeowners Associations, 130 U. PA. L. REv. 1519 (1982); Uriel Reichman, Residential Private Governments: An Introductory Survey, 43 U. CHr. L. Rev. 253 (1976). Cf. Sax, supra note 30 , at 548-57. 
tions and should be commended. Their analysis does not demonstrate, however, that complete reliance on this mechanism is the preferred institutional choice for all circumstances. Rather, it suggests that comparative institutional analysis should be sensitive to the transaction costs of organizing interested parties and resolving disputes privately.

Much of Anderson and Leal's confidence in free market solutions derives from their resilient trust in the market's ability to generate innovations that will reduce the transaction costs of private dispute resolution. ${ }^{47}$ Extrapolating from the barbed wire example, Anderson and Leal express great optimism throughout the book that the market, through "entrepreneurial imagination," 48 will generate propertizing innovations as they are needed. A recitation of some of the innovations that Anderson and Leal believe could be promising means of allowing the market to address natural resource and environmental problems exposes the eccentricity of their own imaginations. With respect to protecting wildlife and endangered species, Anderson and Leal write:

Some environmental groups have proposed that wolves be re-introduced into Yellowstone National Park, but ranchers oppose the plan because they fear that the wolves will leave the park and prey on livestock. Could the wolves be fenced? ... When red wolves were re-introduced into South Carolina wildlands, they were equipped with radio collars that allow the animals to be tracked. If a wolf wanders too far afield, a radio-activated collar injects the animal with a tranquilizing drug so that it can be returned to its designated habitat. Whales also can be "branded" by genetic prints and tracked by satellites, providing another way to define property rights. ${ }^{49}$

Even if feasible on a significant scale, such technologies compromise the objective of wildlife preservation: Allowing wild animals to roam freely without human influence is fundamental to their existence as wild animals.

With regard to global climate change, Anderson and Leal note:

Tracers (odorants, coloring agents, isotopes) might be added to pollutants to ensure the damages were detected early

47. See ANDERson \& Leal, supra note 2, at 17-20.

48. Id. at 21 .

49. Id. at 34 . 
where the costs of reduction were lower. Detection and monitoring schemes would evolve as environmental values mounted and it became appropriate to expend more on fencing. There are exotic technologies that might well play a fencing role even for resources as complex as airsheds. For example, lasimetrics, a technology which can already map atmospheric chemical concentrations from orbit, might in time provide a sophisticated means of tracking transnational pollution flows. If that system were combined with a system under which each nation adopted some fingerprinting system to identify its major greenhouse gases (a type of chemical zip code system), it would become possible to trace pollution to its source and thus make it possible to make the polluters pay. ${ }^{50}$

Anderson and Leal provide no explanation for why the world should wait for the development of electronic fencing or tracing technologies before confronting these problems, other than the utter impotence of public institutions. ${ }^{51}$ Although the market does create incentives for the development of appropriable propertizing innovations, there is no guarantee that such innovations will materialize when needed. Moreover, privately developed new technologies usually do not solve externality problems immediately. Many private inventions are patented and thus allow the inventor to extract monopoly profits for a time, thereby slowing the diffusion of the innovation.

Nor does it necessarily follow that the free market is the best system for generating propertizing technological advancements or implementing such technologies. Economies of scale in research and difficulties in appropriating returns to innovation may enable even highly imperfect public institutions to outperform private entrepreneurs in some technological fields. Furthermore, as the lasimetrics discussion above indicates, government plays important roles in implementing even a free market solution to global climate change. Clearly, the possibility of innovative propertizing technologies does not justify exclusive reliance on free market solutions to address all natural resource and environmental problems.

50. Id. at 166 (quoting Fred L. Smith, Jr., Controlling the Environmental Threat to the Global Liberal Order (Nov. 1989) (paper presented to the Mont Pelerin Socicty, Christchurch, New Zealand)).

51. Id. at 167. 


\section{The Limitations of Legal Institutions}

The third mechanism by which the free market solves environmental problems is the use of common law courts to protect private property rights. Where private $e x$ ante negotiations fail to prevent environmental disputes, Anderson and Leal would rely upon legal institutions and the common law to ensure that property rights are protected and personal injuries compensated. ${ }^{52}$ By identifying the cause of environmental harms, assessing the behavior of the actors responsible for such harms, and quantifying the harm to the victims, common law courts can provide compensation to victims while internalizing the social costs of harm-producing activities. ${ }^{53}$ The legal system, however, is a highly imperfect and costly mechanism for resolving most types of environmental disputes. ${ }^{54}$

Anderson and Leal's favorable impression of the legal system's ability to effectively resolve environmental disputes reflects their naivete about legal institutions. To address the problems posed by acid deposition, for example, Anderson and Leal suggest the following:

Using . . . tracer techniques, it would be possible to identify power plants that are most responsible for acid rain problems in the Northeast. With the sources of pollutants identified, polluters could be forced to pay for the damages they cause. If $\mathrm{SO}_{2}$ pollution affects visibility, then property values will reflect the damages, thus giving property owners the basis for seeking damages or injunctions. In the case of surface water acidity, establishing private rights to water would give the owners similar standing in courts. Where the damages are localized and identifiable, expensive, nationwide solutions become unnecessary. ${ }^{55}$

Even putting aside questions about the technological feasibility and reliability of tracer techniques, this passage reflects an extraordinarily naive view of both the nature of acid deposition and the judicial system. In view of the great expense of bringing a common law action (and the American rule that each side bear its own litigation expenses), prospective plaintiffs would unlikely be able to finance such a case. Free-rider problems

52. See id. at 20.

53. See William H. Landes \& Richard A. Posner, The Economic Structure of TORT LAW (1987).

54. See generally Peter S. Menell, The Limitations of Legal Institutions for Addressing Environmental Risks, 5 J. Econ. Pers. 93 (1991).

55. ANDERSON \& LEAL, supra note 2, at 166-167. 
would reduce the incentive for individuals to invest resources in bringing a case and might inhibit others from participating.

Were these impediments to be overcome, perhaps through class action suits organized by entrepreneurial lawyers, plaintiffs would have to identify the sources of the pollution. In view of the long distance transport of acid deposition precursors, tracers would have to be used over a broad geographic area. Variability of atmospheric and wind conditions would require extensive testing at the sources as well as the downwind receptors. Unless the government were to conduct such monitoring, court orders would likely be needed in numerous states to compel monitoring. Defendants could challenge such on-site tests and delay their implementation, unless, of course, many substantive and procedural protections of private property were to be abolished.

Preparation of the plaintiffs' case would require enormous data gathering efforts and extensive data evaluation by experts. Each defendant would incur great expense to evaluate the plaintiffs' evidence, as well as to develop its own. Tens if not hundreds of sources would likely have some responsibility for pollution in a downwind location. In fact, since nitrogen oxides emitted by automobiles are a precursor of acid deposition, the number of parties could possibly reach millions. Numerous challenges to bringing these many parties before the court would ensue. Out-of-state defendants would have some particularly interesting procedural challenges, such as the lack of personal jurisdiction or form non conveniens. Once in court, there would be evidentiary battles involving complex scientific disputes regarding the accuracy and representativeness of the tracer data and the validity of acid deposition and its effects. Such a case would also raise novel legal questions about the standard of liability, the theory for allocating responsibility, and the appropriate remedy. Were such a case ever to reach "final" judgment, additional battles would ensue in implementing the ruling, not to mention years of appeals. Yet this process assumes that a case is pursued beyond the initial step, which in view of the foregoing is highly unlikely.

It is unrealistic to expect that acid deposition cases, other air pollution claims, toxic tort suits, waste clean-up cases, or water pollution actions will prove effective mechanisms for internalizing pollution costs. As much as Anderson and Leal would like 
to believe that these cases would be straightforward matters to resolve, the nature of legal institutions suggests (and extensive experience with environmental cases confirms) that these cases will generate extraordinarily complex, protracted, and expensive litigation. The legal system employs a highly formalistic, and hence labor-intensive, process for considering cases. Evidentiary standards, procedural protections, and complex doctrines preclude simple resolutions. The adversary process and lawyers' incentives generally contribute little to minimizing the costs of resolving disputes. Moreover, given the decentralized, generalized nature of legal institutions and the random process typically used for assigning cases, most judges would have little if any experience in handling these types of cases. More importantly, judges and juries rarely possess the scientific knowledge needed to address the complex technical issues presented in pollution-related cases. Overall, courts are poorly suited to resolving such disputes. ${ }^{56}$

Once it is recognized that our common law legal system is a highly imperfect and expensive institution for resolving many environmental disputes, the case for free market environmentalism is substantially weakened in many areas of environmental pollution. At a minimum, responsible policy analysis requires careful consideration of a much broader range of institutional arrangements. Anderson and Leal struggle throughout the book, however, to avoid constructive consideration of public institutions. The following section analyzes the basis for Anderson and Leal's steadfast rejection of public institutions as effective means of accomplishing anything desirable.

\section{The Complexity of Public Institutions}

Anderson and Leal's Sanguine view of markets and legal institutions contrasts sharply with their deeply cynical perception of public institutions. ${ }^{57}$ Using a simplistic and cursory application of public choice theory, Anderson and Leal portray public institutions as monolithic, centralized structures wholly incapa-

56. It comes as some relief to see that Anderson and Leal do acknowledge the freerider and causation limitations of legal institutions in the context of water pollution, see id. at $139-40$, but their preferred solution to these problems is to rely on ex ante negotiations between polluters and receptors of discharge. See id. at 147-49. The impediments to these solutions, however, were the reasons that Anderson and Leal turned to ex post legal institutions in the first place.

57. See id. at 12-22. 
ble of effectively addressing natural resource or environmental problems. ${ }^{58}$ In their view, these institutions are established by legislators driven by the pursuit of re-election in efforts to appease rent-seeking special interests. Such bureaucracies are highly centralized command and control centers, incapable of gathering or processing the diffuse information that would be needed to allocate resources efficiently. Even if these bureaucracies could manage the information, the self-interest of resource managers leads them to allocate resources in accordance with special interest support. Not surprisingly, this impoverished caricature of public institutions leads Anderson and Leal to reject any significant role for the public sector outside of defining and enforcing property rights. ${ }^{59}$

While some horror stories of public mismanagement of natural resources and environmental policy lend credence to Anderson and Leal's account-below-cost timber sales, water subsidies, and aspects of the Clean Air Act of 1977 come to mind $^{60}$ - their conclusory portrayal of public institutions precludes a careful analysis of institutional choice. Public institutions are complex bodies capable of taking varying forms. Understanding this complexity and the potential for institutional reform is critical to advancing the policy debate.

Anderson and Leal's reading of public choice theory is both overly literal and impressionistic. As discussed above, the standard economic model of human nature is not meant as a complete description of human character, but as a useful construct for predicting behavior. Similarly, the single-minded legislator seeking re-election, or the single-minded bureaucrat seeking an expanded budget, are constructs, not intended to be complete representations of political actors. In fact, a substantial body of empirical literature comes to less superficial conclusions about the motivations of government officials and indicates that ideology may be a better predictor of voting behavior than economic factors. ${ }^{61}$ Studies of bureaucratic decisionmaking also

58. See id. Chapters 1 and 2 lay out the theoretical assumptions underlying their views of public institutions. The remainder of the book adds little to this simplistic account.

59. See id. at 22-23.

60. See, e.g., Bruce A. Ackerman \& William T. Hassler, Clean Coal/Dirty Air: Or How the Clean Air Act Became a Multibillion-Dollar Bail-OUt for Higu Sulfur Coal Producers and What Should Be Done About It (1981).

61. See Joseph P. Kalt \& Mark A. Zupan, Capture and Ideology in the Economic Theory of Politics, 74 Am. Econ. Rev. 279 (1984); James B. Kau \& Paul H. Rubin, Self-Interesi, 
suggest a much more complex theory of administrative behavior. ${ }^{62}$ Recognition of the multi-dimensional nature of political actors is obviously of great importance to evaluating the potential efficacy of public institutions.

Beyond their simplistic image of public decisionmakers, Anderson and Leal's cursory application of public choice theory always seems to conclude that bureaucracies will badly misallocate resources. ${ }^{63}$ One gets the impression from their analysis that public choice theory always predicts that bureaucracies will be highly inefficient. This is simply not the case. Rather, public choice theory predicts that the efficacy of public institutions depends on the motivations and alignments of interest groups. ${ }^{64}$ Not all interest group alignments spell disaster for public institutions. Some alignments are consistent with reasonably efficacious government. Yet Anderson and Leal provide little systematic analysis of how the relevant interest groups are aligned in the various areas of natural resources and environmental policy. In view of the heterogeneity of natural resource and environmental issues and the changing character of the political arena, Anderson and Leal's broad-brush conclusions obscure important insights.

A review of current trends in the policy arena suggests that a favorable climate is developing for better environmental policy within public institutions. ${ }^{65}$ In the formative years of modern environmental legislation, environmental groups participated in the political process episodically, mainly publicizing symbolic positions of legislators. They were extremely naive political players, believing that direct federal control of industrial activity was the most effective means of controlling pollution. In this climate, public choice theory would predict outcomes

Ideology, and Logrolling in Congressional Voting, 22 J.L. \& Econ. 365 (1979). See generally Herbert Hovenkamp, Legislation, Well-Being, and Public Choice, 57 U. CHI. L. Rev. 63, 88 (1990); Daniel A. Farber \& Phillip P. Frickey, The Jurisprudence of Public Choice, 65 TEx. L. REv. 873, 890-99 (1987).

62. See Steven Kelman, Making Public Policy: A Hopeful. View of American Government (1987); Herbert A. Simon, Administrative Behavior: A Study in DecisionMaking Processes in Administrative Organization (3d ed. 1976).

63. See Anderson \& Leal, supra note 2, at 22-23, 125-28.

64. See Michael T. Hayes, Lobbyists and Legislators (1981); James Q. Wilson, Political. Organizations (1973); George J. Stigler, The Theory of Economic Regulation, 2 Bell J. Econ. \& Mgmt. Sci. 3 (1971); Carl A. Salisbury, An Exchange Theory of Interest Groups, 13 Midwest J. Pol. Sci. 1 (1969); Mancur Olson, JR., The Logic of Collective Actions: Public Goods and the Theory of Groups (1965).

65. See Robert W. Hahn \& Robert N. Stavins, Incentive-Based Environmental Regulation: A New Era from an Old Idea?, 18 Ecolocy L.Q. 1 (1991). 
similar to those observed-symbolic legislation delegating authority to agencies prone to capture. Two decades of mixed results have sobered many environmental organizations to the realities of command-and-control regulation while greater public interest in the environment has enriched their coffers. As a result, many environmental groups have become more regular and sophisticated players in the policy formation and implementation arenas. The most influential of such groups now appreciate the need to achieve environmental goals costeffectively, prioritize spending on the environment, and consider the economic costs of environmental protection. The support of many leading environmental organizations for decentralized, economic incentive measures included in the Clean Air Act Amendments of $1990^{66}$ reflects these trends. From a public choice perspective, these shifts in the interest group alignment surrounding environmental policy suggest that more responsible regulatory structures are now possible, at least within some areas of environmental policy.

The recognition by environmental groups that cost-effectiveness should matter and that decentralized, economic incentive approaches may be more effective than command-and-control mechanisms would seem to suggest that there is significant common ground among the major interest groups affecting environmental policy. Of course, industry lobbyists would likely oppose high environmental quality standards, but they should welcome cost-effective, incentive-based programs. This coalescence in the environmental policy arena suggests a less sinister view of some environmental regulation than that espoused by Anderson and Leal: Regulation through public institutions can represent a mutually-beneficial and socially more efficient means of resolving disputes among affected parties. ${ }^{67}$ Such an arrangement need not be an exercise in rent-seeking as it is in sharing the efficiency gains of better institutional arrangements. For example, in view of the high costs of resolving acid deposition disputes in the courts pursuant to Anderson and Leal's free market environmentalist solution, ${ }^{68}$ it is not hard to

66. Clean Air Act Amendments of 1990, Pub. L. No. 101-549, 104 Stat. 2399 (1990). 67. Cf. Richard B. Stewart, Economics, Environment, and the Limils of Legal Control, 9 HaRv. ENVTL. L. Rev. 1 (1985) (arguing that "the presumed conflict between environmental and economic development is in large measure a false one"); Ruth Walker, Project 88, Round II: Bejond False Choices, Christian Scr. Monitor, June 5, 1991, at 19. 68. See Anderson \& Leal, supra note 2, at 166-67. 
imagine a common interest among polluters and receptors in identifying more efficient institutional structures. ${ }^{69}$ Of course, such structures would have to be carefully designed to ensure that these interest groups do not impose costs upon others who are not adequately represented in the political process. This brings us to important questions of institutional design.

Anderson and Leal's portrayal of public institutions as federal, monolithic, unbridled, highly centralized, command-andcontrol bureaucracies precludes careful analysis of institutional design. Contrary to this depiction, government bureaucracies reflect a broad array of design features: jurisdictional level, command structure, degree of centralization, incentive structure for agency officials, and policy approach, among others. Hybrid regulatory structures can incorporate many of the advantages of both public and private institutions, with few of the drawbacks of either. ${ }^{70}$ Moreover, heightened concern about regulatory inefficiency has generated enhanced executive, legislative, and judicial checks on federal agency decisionmaking. ${ }^{71} \mathrm{~A}$ responsible analysis of institutional choice requires consideration of the broad array of actual and potential public institutions and the many checks and balances available for improving and constraining regulators' behavior.

\section{Conclusions}

Where does this leave us? Free market environmentalism, at

69. In order to make this solution acceptable to polluters, the receptors might have to give up the right to bring private law suits for damage attributable to acid deposition. On the other hand, because the effects of acid deposition are cumulative, an effective regulatory program would likely reduce the effects below legally cognizable levels.

70. See, e.g., Project 88, supra note 7 (discussing various economic incentive-based approaches to natural resources and environmental problems); Hahn \& Stavins, supra note 65, at 3-5; Peter S. Menell, Beyond the Throwaway Saciely: An Incentive Approach to Regulating Municipal Solid Waste, 17 Ecolocy L.Q. 655 (1990); Bruce A. Ackerman \& Richard B. Stewart, Reforming Environmental Law: The Democratic Case for Market Incentives, 13 Colum. J. ENvTL. L. 171 (1988); Susan Rose-Ackerman, Reforming Public Bureaucracy through Economic Incentives?, 2 J.L. Econ. \& ORG. 131 (1986); Lee S. Friedman, Public Institutional Structure and Resource Allocation: The Analysis of Adjustment, $2 \mathrm{~J}$. PoL. ANaL. \& MgmT. 303 (1981).

Anderson and Leal acknowledge that effluent charges and tradeable permit approaches overcome many of the problems associated with command-and-control regulation. See ANDERSon \& LeAL, supra note 2, at 144-47. Nonetheless, they still favor free market solutions, because economic incentive systems require a political determination of the level of pollution that will be allowed. See id. at 147. It should be noted that Anderson and Leal do not seem to mind such determinations being made by nonexpert, uncoordinated judges and juries through common law suits.

71. See generally Cass R. Sunstein, Constitutionalism After the New Deal, 101 Harv. L. REv. 421 (1987). 
least as espoused by Anderson and Leal, is no less a fantasyland than is scientific management. Traditional economic analysis illuminates the public end of the institutional spectrum. Anderson and Leal have shed light on the private extreme. A complete theory of institutional analysis must provide a clear understanding of the principal attributes, both strengths and weaknesses, of the full range of institutional alternatives. Only with this background and a thorough appreciation of the resource allocation problem to be addressed can sound recommendations for institutional choice be devised. To quote again from Bureaucracy vs. Environment: "Most simple answers are either wrong or incomplete."72 This caution applies with equal force to both scientific management and free market environmentalism.

72. BUREAUCRACY vs. ENvironment, supra note 1, preface (1981). 